\title{
Therapeutic effects of antimicrobial peptide on malignant ascites in a mouse model
}

\author{
LI-JIE XIA, YAN-LING WU, JI MA and FU-CHUN ZHANG \\ Xinjiang Key Laboratory of Biological Resources and Genetic Engineering, College of Life \\ Science and Technology, Xinjiang University, Urumqi, Xinjiang 830046, P.R. China
}

Received May 11, 2016; Accepted April 13, 2017

DOI: $10.3892 / \mathrm{mmr} .2018 .8691$

\begin{abstract}
The primary objective of the treatment of malignant ascites in advanced stages is to alleviate symptoms using procedures such as diuresis, paracentesis of subretinal fluid and vena cava anastomosis. The effectiveness of systemic or intraperitoneal chemotherapy treatment is limited, and more efficacious therapies are required. The authors of the present study demonstrated that an antimicrobial peptide, cecropinXJ, isolated from the larvae of Bombyx mori, selectively inhibits the proliferation of gastric cancer cells. However, the effects of antibacterial peptides on gastric ascites tumor remains unclear. In the present study, the therapeutic effects of cecropinXJ were investigated in mice bearing malignant ascites. Compared with bovine serum albumin treatment, cecropinXJ and doxorubicin (Dox) significantly inhibited the formation and growth of malignant ascites, and prolonged the survival time of ascites tumor-bearing mice. In addition, cecropinXJ treatment normalized the hematological and biochemical phenotypes, induced tumor cell apoptosis in ascites and improved the survival of mice bearing malignant ascites when compared with Dox treatment. These results suggested that cecropinXJ might be a promising therapeutic candidate for the treatment of gastric cancer-associated ascites.
\end{abstract}

\section{Introduction}

The development of malignant ascites is a common complication of advanced or recurrent malignant tumors (1). Primary diseases that lead to malignant ascites primarily include abdominal and pelvic malignant tumors, such as malignant gastrointestinal tumors, ovarian tumors and liver tumors (2). Recurrent malignant ascites increases intra-abdominal

Correspondence to: Professor Fu-Chun Zhang, Xinjiang Key Laboratory of Biological Resources and Genetic Engineering, College of Life Science and Technology, Xinjiang University, 666 Shengli Road, Urumqi, Xinjiang 830046, P.R. China

E-mail: zfcxju@xju.edu.cn

Key words: cecropinXJ, BGC823 gastric cancer cells, malignant ascites, intraperitoneal therapy pressure, abdominal distention, dyspnea and severe loss of body weight, which accelerates disease progression, affects anti-tumor treatment and the patients' quality of life. In addition, patient prognosis is poor once malignant ascites develop. It is reported that $18.3 \%$ malignant ascites occur as a result of gastric cancer (3). The one-year survival rate of patients with gastric cancer is $\leq 10 \%$, and the average survival time is $\leq 6$ months (4). The treatment options for malignant ascites are limited. In the clinic, the primary treatments include dieresis, puncture and aspiration, a peritoneal shunt and systemic or intraperitoneal chemotherapy. Of these, intraperitoneal chemotherapy has become an important treatment for malignant ascites. Chemotherapy drugs are administered into the peritoneal cavity, which may directly kill cancer cells. However, chemotherapy cannot fully and effectively enhance patient survival and control the metastasis of gastric tumors in the peritoneum (5).

Studies have demonstrated that particular antibacterial peptides are cytotoxic to transformed cells, whereas they are less cytotoxic to non-transformed cells $(6,7)$. The antibacterial peptide, cecropin exhibits antitumor activity when injected locally into solid tumors (8).

CecropinXJ is isolated from the larvae of Bombyx mori (B. mori), which has a 37-amino acid cationic antimicrobial peptide sequence with specific amphipathic $\alpha$-helices (9). CecropinXJ demonstrates a broad activity against bacteria and fungi $(10,11)$. Previous studies have revealed that cecropinXJ may inhibit the proliferation of human BGC823 gastric cancer cells in vitro (12), whereas, it demonstrates no hemolytic effects against human erythrocytes and no toxicity to healthy mammalian cells $(13,14)$. However, to the best of the author's knowledge, no relevant studies have been performed to date that explore the effects of cecropin XJ on the growth of tumor-associated ascites in human gastric cancer. In the present study, the therapeutic effects of cecropinXJ were investigated in mice bearing malignant ascites. The results revealed that cecropinXJ may effectively inhibit the formation and growth of malignant ascites and improve the survival of tumor-bearing mice, which was reflected by the normal blood and biochemical indexes, and the lack of toxic effects on the liver, kidney and spleen. These results suggested that cecropinXJ might be utilized as a potential therapeutic drug for the treatment of malignant ascites in patients with gastric cancer. 


\section{Materials and methods}

Preparation of antimicrobial peptide cecropinXJ. The cecropinXJ sequence of $B$. mori was obtained via the Saccharomyces cerevisiae eukaryotic expression system, and purified using a nickel-chelating Sepharose column, as previously described (11). The concentration of purified recombinant cecropinXJ protein was detected using a Bradford protein assay kit (BioTeke Corporation, Beijing, China). The amino acid sequence of cecropinXJ is as follows: WKIFKKIEK MGRNIRDGIVKAGPAIEVLGSAKAIGK. Prior to use, the peptide was dissolved in Dulbecco's modified Eagle's medium (DMEM; HyClone; GE Healthcare Life Sciences, Logan, UT, USA) to a concentration of $1 \mathrm{mg} / \mathrm{ml}$, and sterilized by filtration through a $0.22 \mu \mathrm{m}$ filter.

Cell culture. The human gastric cancer cell line, BGC823, was kindly provided by Professor Youyong Lv (Beijing Cancer Hospital, Beijing, China). BGC823 cells were cultured in DMEM medium supplemented with $10 \%$ fetal bovine serum (Gibco; Thermo Fisher Scientific, Inc., Waltham, MA, USA), $100 \mu \mathrm{g} / \mathrm{ml}$ streptomycin and $100 \mathrm{U} / \mathrm{ml}$ penicillin (HyClone; GE Healthcare Life Sciences), in a humidified atmosphere of $95 \%$ air with $5 \% \mathrm{CO}_{2}$ at $37^{\circ} \mathrm{C}$. Cells growing in the mid-logarithmic growth phase were utilized in all experiments.

Animals. BALB/C mice (weight, 17-22 g; age, 5-6 weeks) were purchased from the Center for Disease Control and Prevention (Xinjiang, China). The animals were maintained at a temperature of $23 \pm 2^{\circ} \mathrm{C}$ and a relative humidity of $50 \pm 10 \%$, with $12 \mathrm{~h}$ light/dark cycles. All experiments were conducted and approved by the Chinese Animal Care for Laboratory Animals (Beijing, China).

Experimental animal grouping and administration. BGC823 cells were suspended in PBS at a concentration of $2 \times 10^{8}$ cells $/ \mathrm{ml}$, and $0.5 \mathrm{ml}$ of the suspension was injected into the peritoneal cavity of each animal. In total, we selected 30 mice with abdominal bulging. Mice were divided into the following 3 groups at random $(n=10)$ : The negative control group, where mice were treated with bovine serum albumin (BSA, $5 \mathrm{mg} / \mathrm{kg}, \mathrm{d}_{1} \sim \mathrm{d}_{10}$; Sigma-Aldrich; Merck KGaA, Darmstadt, Germany); the cecropinXJ treatment group $\left(5 \mathrm{mg} / \mathrm{kg}, \mathrm{d}_{1} \sim \mathrm{d}_{10}\right)$; the positive control group, where mice were treated with doxorubicin (Dox, $5 \mathrm{mg} / \mathrm{kg}, \mathrm{d}_{1} \sim \mathrm{d}_{10}$ ). In addition, we set the healthy group $(n=10)$, where mice were not injected with tumor cells. The concentration of BSA, cecropinXJ and Dox was adjusted with saline, and mice were administered with treatments once every day, for 10 days by intraperitoneal injection. The body weight and abdominal circumference of mice was measured every day. Blood was collected from the posterior orbital venous plexus at $24 \mathrm{~h}$ following the final treatment, in order to measure blood physiological and serum biochemical indexes. In addition, the volume of ascites and rate of apoptosis were determined. Three mice in each group were selected at random and sacrificed by cervical spine dislocation. Ascites supernatant and abdominal viscera samples were collected and stored at $-80^{\circ} \mathrm{C}$. The remaining mice in each group were used for survival analysis.
Body weight analysis. Alterations in appetite, mental state and abdominal circumference of mice in each group were observed. In addition, the body weight of the mice in each group was monitored for a period over 18 days, recorded and used to generate a body weight alteration curve.

Abdominal circumference analysis. Abdominal bulging was observed in all groups, and the abdominal circumference of the mice in each group was measured and recorded daily for 18 days. The values were used to generate a curve of abdominal circumference alterations.

Physiological and biochemical analysis. Blood biochemical factors may alter during the development of a tumor (15). A total of $0.5 \mathrm{ml}$ blood from each mouse was obtained at $24 \mathrm{~h}$ following the final treatment, and blood factors (Hemoglobin, Red blood cells count, White blood cells count and differential leukocyte count) were measured with an automatic blood cell analyzer (Blood Cell Counter 3-Part/Diff Hematology Analyzer, Poweam Medical Co., Itd., Nanjing) according to the manufacturer's protocol. For hepatic and renal function tests, blood was centrifuged at $2,000 \mathrm{xg}$ at $4^{\circ} \mathrm{C}$ for $10 \mathrm{~min}$ to prepare the serum. The levels of albumin, globulin, alanine aminotransferase (ALT), aspartate aminotransferase (AST), urea, creatinine and uric acid were analyzed using the automatic blood cell analyzer according to the manufacturer's protocol.

Volume of ascites in tumor-bearing mice. Three mice in each group were sacrificed by cervical spine dislocation. A laparotomy was performed under aseptic conditions. Ascites fluid was collected and placed in a centrifuge tube, and the volume was measured.

Tumor cell apoptosis in ascites fluid of tumor-bearing mice. Annexin V and propidium iodide (PI) staining was employed to quantify the effect of antimicrobial peptide on apoptosis. Three mice in each group were sacrificed by cervical spine dislocation. A laparotomy was performed under aseptic conditions. Ascites fluid was collected and placed in a centrifuge tube, and used for tumor cell apoptosis analysis. An Annexin V-fluorescein isothiocyanate (FITC) apoptosis detection kit (BestBio Biotechnologies, cat. no. 401003, Shanghai, China) was used according to the manufacturer's protocol, and the results were quantified by flow cytometric analysis. Briefly, cells of ascites fluid were collected and washed with ice-cold phosphate-buffered saline (PBS) prior to detaching cells with trypsin. Cells were centrifuged at $2,000 \mathrm{x}$ g for $5 \mathrm{~min}$ at $4^{\circ} \mathrm{C}$ and resuspended in $400 \mu \mathrm{l}$ PBS. Cells were centrifuged again for $5 \mathrm{~min}$ at $4^{\circ} \mathrm{C}$, resuspended in $200 \mu \mathrm{l}$ Annexin $\mathrm{V}$ binding buffer, and incubated with Annexin V-FITC (5 $\mu \mathrm{l})$ and PI $(10 \mu \mathrm{l})$ at $4^{\circ} \mathrm{C}$ for $15 \mathrm{~min}$ in the dark. Cells were analyzed using a FACScan flow cytometer with CellQuest software version 3.0 (BD Biosciences, Franklin Lakes, NJ, USA).

Determination of the liver-body weight ratio, and the thymus and spleen index. The spleen, thymus and liver of sacrificed mice as described earlier were removed and weighed. The hepatosomatic index, kidney somatic index, thymus index and spleen index were calculated according to the following formulae: Hepatosomatic Index (HSI)=liver weight (g)/body weight (g); 

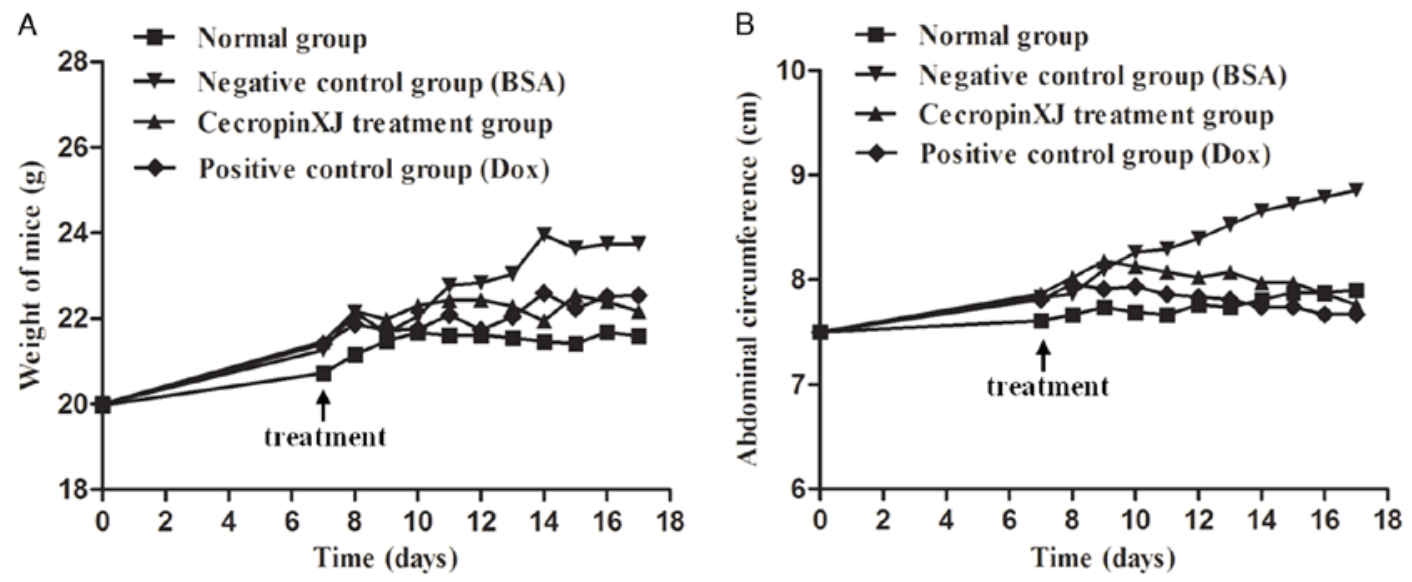

Figure 1. Successful establishment of the BGC823 ascites model in mice. The (A) body weight and (B) abdominal circumference of mice in the normal healthy, negative control (BSA), cecropinXJ and Dox positive control groups were measured. Data are presented as the mean of three independent experiments. BSA, bovine serum albumin; Dox, doxorubicin.

kidney somatic index $(\mathrm{KSI})=$ kidney weight $(\mathrm{mg}) /$ body weight $(\mathrm{g})$; thymus index=thymus weight $(\mathrm{mg}) /$ body weight $(\mathrm{g}) \mathrm{x} 10$; spleen index $=$ spleen weight $(\mathrm{mg}) /$ body weight $(\mathrm{g}) \mathrm{x} 10$.

Metastasis to abdominal viscera of mice. The spleen, thymus and liver that were removed from mice were weighed, fixed in $10 \%$ formalin solution at room temperature for $24 \mathrm{~h}$ and embedded in a paraffin block. The paraffin block was cut into $5 \mu \mathrm{m}$ sections and stained with hematoxylin and eosin at room temperature for $5 \mathrm{~min}$. The pathological alterations, including inflammation, necrosis, mitotic index and apoptosis index from 5 random fields were observed under an optical microscope (data not shown).

Survival time of tumor-bearing mice. The survival of the seven remaining mice in each group was recorded for 30 days, and the increase in life span was calculated according to the following formula: Increase in life $\operatorname{span}(\%)=(\mathrm{T} / \mathrm{C}-1) \times 100$, where $\mathrm{T}$ represented the average survival (days) of mice in each treatment group, and $\mathrm{C}$ represented the average survival (days) of mice in the negative control group.

Statistical analysis. Experiments were repeated at least three times. Data are expressed as the mean \pm standard deviation. A Student's t-test was used to analyze differences between two groups, whereas differences among $\geq 3$ groups were analyzed using one-way analysis of variance followed by a Newman-Keuls test. SPSS software (version, 13.0; SPSS, Inc., Chicago, IL, USA) was used to analyze the data. $\mathrm{P}<0.05$ was considered to indicate a statistically significant difference.

\section{Results}

CecropinXJ inhibits ascites development in mice. Body weight and abdominal circumference measurements are direct indexes for determining the development of abdominal ascites tumors in mice $(16,17)$. The body weight and abdominal circumference of normal healthy mice increased at a steady rate, whereas $\mathrm{BGC} 823$ tumor-bearing mice exhibited a sharp increase in body weight and abdominal circumference (Fig. 1). This suggested that the BGC 823 ascites model was successfully

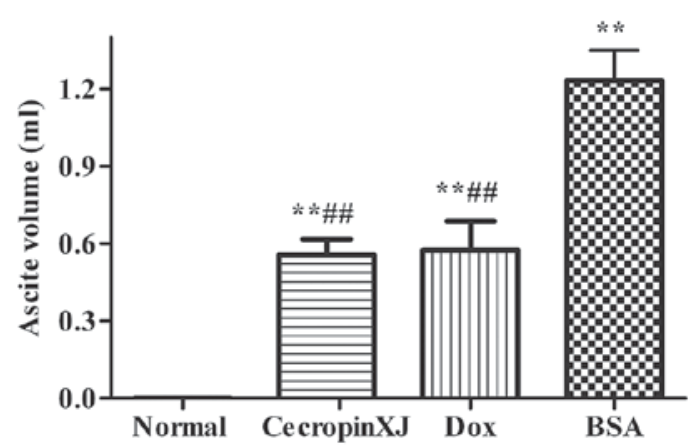

Figure 2. Ascites fluid was collected and the volume was measured in normal healthy mice or tumor-bearing mice treated with BSA, cecropinXJ or Dox. Data are presented as the mean \pm standard deviation of three independent experiments. ${ }^{* *} \mathrm{P}<0.01$ vs. normal untreated control group; ${ }^{\# \#} \mathrm{P}<0.01$ vs. BSA-treated group. BSA, bovine serum albumin; Dox, doxorubicin.

established. To determine the effect of cecropinXJ on malignant ascites formation and tumor growth, mice bearing ascites tumors were administered with cecropinXJ for 10 consecutive days. When compared with the BSA control group, the body weight of mice in the cecropinXJ and Dox treatment groups increased slowly and the abdominal circumference started to decrease at 4 days following the commencement of treatment (Fig. 1). The inhibitory effect of cecropinXJ on the body weight and abdominal circumference of mice was similar to Dox treatment. At the end of treatment, the body weight and abdominal circumference of mice in the cecropinXJ treatment group was reduced by 6.61 and $12.36 \%$, respectively, when compared with the BSA control group (Fig. 1). The body weight and abdominal circumference of mice in the Dox treatment group were reduced by 6.05 and $12.69 \%$, respectively, when compared with the BSA control group (Fig. 1).

Ascites formation in mice. Ascites formation was significantly inhibited by cecropinXJ (Fig. 2). The ascites volume of tumor-bearing mice in the BSA control, cecropinXJ and Dox treatment groups was $1.23,0.57$ and $0.55 \mathrm{ml}$, respectively. The ascites volume in mice treated with cecropinXJ and Dox was significantly reduced when compared with the BSA control 

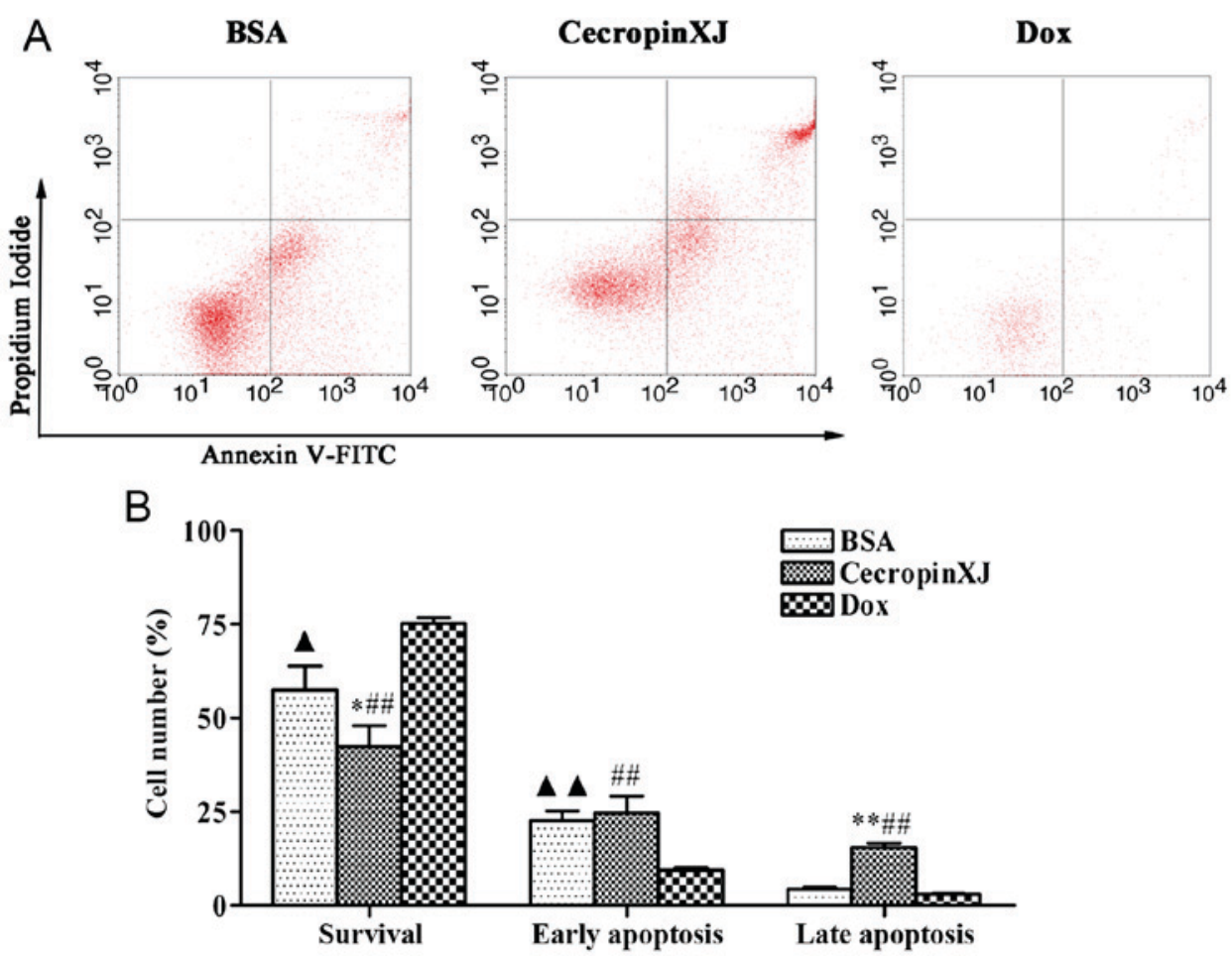

Figure 3. Apoptosis analysis of tumor cells in the ascites fluid of mice from each group, as determined by staining with Annexin V-FITC/propidium iodide and flow cytometry analysis. (A and B) Tumor cells were derived from mice that had been treated with BSA, cecropinXJ or Dox, and were collected and subjected to Annexin V-FITC/propidium iodide staining, and analyzed by flow cytometry and the percentage of apoptotic cells is shown. Data are representative of three independent experiments. ${ }^{*} \mathrm{P}<0.05$ and ${ }^{* *} \mathrm{P}<0.01$ vs. BSA group; ${ }^{\# \#} \mathrm{P}<0.01$ vs. Dox group; ${ }^{\mathbf{\Lambda}} \mathrm{P}<0.05$ and ${ }^{\boldsymbol{\Lambda} \mathbf{\Delta}} \mathrm{P}<0.01$ vs. Dox group. FITC, fluorescein isothiocyanate; BSA, bovine serum albumin; Dox, doxorubicin.

group $(\mathrm{P}<0.01)$; however, there was no significant difference between the cecropin XJ and Dox treatment groups (Fig. 2).

Apoptosis of tumor cells in ascites fluid of tumor-bearing mice. Apoptosis of tumor cells in ascites fluid was detected by flow cytometry analysis. As demonstrated in Fig. 3, cecropinXJ treatment increased the level of apoptosis in ascites fluid-derived tumor cells. Apoptosis increased from $21.25 \pm 2.13$ (BSA) to $32.18 \pm 4.36$ (cecropinXJ; Fig. 3). The results suggested that intraperitoneal injection of cecropinXJ into tumors may inhibit tumor growth, prevent the formation of ascites fluid and induce apoptosis of tumor cells.

Prolongation of cecropinXJ on survival time of tumor-bearing mice. Effective anti-tumor chemotherapy drugs may significantly prolong the survival of tumor-bearing mice. In the present study, tumor-bearing mice were treated with BSA, cecropinXJ or Dox for 10 consecutive days and the survival time was recorded. The increase in life-span of tumor-bearing mice in the cecropinXJ treatment group was $66 \%$, whereas the increase in survival of mice treated with Dox was $63 \%$ when compared with the BSA control group (Fig. 4).

Effect of cecropinXJ on blood parameters. The level of routine blood factors in mice from each group was analyzed, and included red and white blood cell counts and hemoglobin levels. During the development of a tumor, the levels of hemoglobin and red blood cells are frequently reduced, whereas the white blood cell count is increased (18). As demonstrated in Table I, treatment with cecropinXJ and

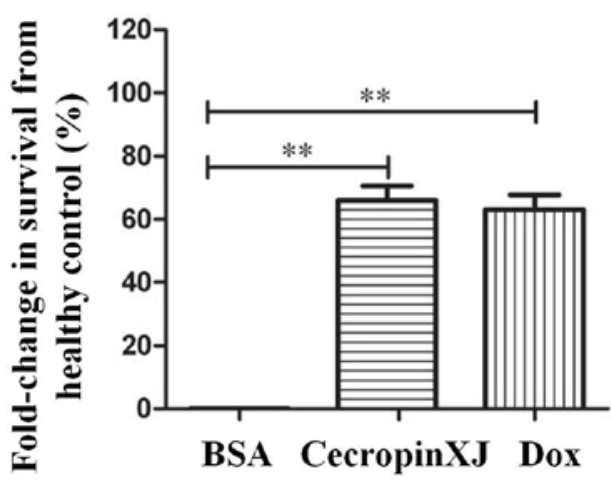

Figure 4. CecropinXJ and Dox prolonged the survival of tumor bearing mice. Data are presented as the mean \pm standard deviation of three independent experiments. ${ }^{* *} \mathrm{P}<0.01$ as indicated. Dox, doxorubicin; BSA, bovine serum albumin.

Dox resulted in enhanced levels of hemoglobin $(\mathrm{P}<0.01)$ and red blood cells $(\mathrm{P}<0.05)$, and significantly reduced the white blood cell count $(\mathrm{P}<0.01)$ when compared with mice treated with BSA.

Effect of cecropinXJ on hepatic and renal function. Blood biochemical indexes of mice in each group were measured, including indicators of liver function, such as albumin, globulin, ALT, AST and indicators of renal function, such as urea, creatinine and uric acid levels. As demonstrated in Table II, almost all parameters in mice from the BSA control group were significantly altered when compared 
Table I. Blood hematological index in mice.

\begin{tabular}{lcccc}
\hline Parameter & $\begin{array}{c}\text { Healthy } \\
\text { mice group }\end{array}$ & $\begin{array}{c}\text { Negative control } \\
\text { group (BSA) }\end{array}$ & $\begin{array}{c}\text { CecropinXJ } \\
\text { treatment group }\end{array}$ & $\begin{array}{c}\text { Positive control } \\
\text { group (Dox) }\end{array}$ \\
\hline Hemoglobin $(\mathrm{g} / \mathrm{l})$ & $153.67 \pm 0.58$ & $100.50 \pm 0.71^{\mathrm{b}}$ & $123.5 \pm 0.71^{\mathrm{d}}$ & $131.33 \pm 2.89^{\mathrm{d}}$ \\
RBC $\left(10^{9}\right.$ cells/ml) & $10.05 \pm 0.19$ & $8.37 \pm 0.51^{\mathrm{b}}$ & $9.15 \pm 0.01^{\mathrm{c}}$ & $9.56 \pm 0.25^{\mathrm{c}}$ \\
WBC $\left(10^{6}\right.$ cells/ml) & $2.73 \pm 0.18$ & $7.19 \pm 0.46^{\mathrm{b}}$ & $4.52 \pm 0.27^{\mathrm{d}}$ & $5.19 \pm 0.25^{\mathrm{a}, \mathrm{d}}$ \\
Platelet $\left(10^{6}\right.$ cells/ml) & $563.00 \pm 32.70$ & $996.5 \pm 416.49^{\mathrm{b}}$ & $878.00 \pm 410.12^{\mathrm{a}}$ & $1,139.33 \pm 150.19^{\mathrm{b}}$ \\
Neutrophils $(\%)$ & $22.43 \pm 0.86$ & $24.70 \pm 0.29$ & $27.20 \pm 0.71$ & $25.77 \pm 0.93$ \\
Lymphocytes $(\%)$ & $77.23 \pm 1.36$ & $93.95 \pm 1.06^{\mathrm{a}}$ & $92.25 \pm 1.48$ & $92.27 \pm 0.75$ \\
Monocytes $(\%)$ & $0.33 \pm 0.56$ & $1.75 \pm 0.21$ & $0.55 \pm 0.78$ & $1.97 \pm 0.42^{\mathrm{a}}$ \\
\hline
\end{tabular}

Data are expressed as the mean \pm standard error of three mice in each group. ${ }^{\mathrm{a}} \mathrm{P}<0.05$ and ${ }^{\mathrm{b}} \mathrm{P}<0.01$ vs. healthy group. ${ }^{\mathrm{c}} \mathrm{P}<0.05$ and ${ }^{\mathrm{d}} \mathrm{P}<0.01$ vs. BSA group. BSA, bovine serum albumin; Dox, doxorubicin; RBC, red blood cell; WBC, white blood cell.

Table II. Blood physiochemical indexes in mice.

\begin{tabular}{lcccc}
\hline Parameters & $\begin{array}{c}\text { Healthy } \\
\text { mice group }\end{array}$ & $\begin{array}{c}\text { Negative control } \\
\text { group (BSA) }\end{array}$ & $\begin{array}{c}\text { CecropinXJ } \\
\text { treatment group }\end{array}$ & $\begin{array}{c}\text { Positive control } \\
\text { group (Dox) }\end{array}$ \\
\hline Albumin $(\mathrm{g} / \mathrm{l})$ & $30.37 \pm 0.60$ & $26.87 \pm 0.47^{\mathrm{a}}$ & $26.60 \pm 0.71$ & $27.25 \pm 0.64$ \\
Globulin $(\mathrm{g} / \mathrm{l})$ & $21.27 \pm 1.55$ & $27.27 \pm 0.93^{\mathrm{a}}$ & $30.60 \pm 0.71^{\mathrm{a}}$ & $28.25 \pm 2.76^{\mathrm{a}}$ \\
ALT $(\mathrm{U} / \mathrm{l})$ & $41.33 \pm 2.31$ & $52.33 \pm 5.85^{\mathrm{a}}$ & $31.50 \pm 0.71^{\mathrm{d}}$ & $40.00 \pm 2.83^{\mathrm{c}}$ \\
AST (U/l) & $115.33 \pm 3.78$ & $129.33 \pm 5.86^{\mathrm{a}}$ & $117.50 \pm 0.71^{\mathrm{c}}$ & $102.5 \pm 6.36^{\mathrm{d}}$ \\
BUN $(\mathrm{mmol} / \mathrm{l})$ & $6.33 \pm 0.21$ & $8.17 \pm 0.21^{\mathrm{b}}$ & $6.70 \pm 0.28^{\mathrm{d}}$ & $5.80 \pm 0.56^{\mathrm{d}}$ \\
CR $(\mu \mathrm{mol} / \mathrm{l})$ & $10.77 \pm 1.63$ & $11.67 \pm 2.57$ & $11.45 \pm 0.64$ & $179.09 \pm 0.26^{\mathrm{c}}$ \\
Uric acid $(\mu \mathrm{mol} / \mathrm{l})$ & $177.92 \pm 14.37$ & $143.23 \pm 1.67^{\mathrm{a}}$ & $150.805 \pm 13.14^{\mathrm{a}}$ \\
\hline
\end{tabular}

Data are expressed as the mean \pm standard error of three mice in each group. ${ }^{a} \mathrm{P}<0.05$ and ${ }^{\mathrm{b}} \mathrm{P}<0.01$ vs. healthy group. ${ }^{\mathrm{c}} \mathrm{P}<0.05$ and ${ }^{\mathrm{d}} \mathrm{P}<0.01$ vs. BSA group. BSA, bovine serum albumin; Dox, doxorubicin; ALT, alanine aminotransferase; AST, aspartate aminotransferase; BUN, blood urea nitrogen; $\mathrm{CR}$, creatinine.

with the normal healthy control group, indicating that the liver and kidney may have been damaged. However, treatment with cecropinXJ reversed these alterations in hepatic and renal function in mice. Compared with BSA-treated mice, ALT, BUN $(\mathrm{P}<0.01)$ and $\mathrm{AST}(\mathrm{P}<0.05)$ were reduced, and Uric acid $(\mathrm{P}<0.05)$ were enhanced in cecropinXJ-treated mice.

Effect of cecropinXJ on viscera of mice. The abdominal viscera, including the liver, kidney and spleen of sacrificed mice were subjected to hematoxylin and eosin staining, and pathological factors, including infiltration, inflammation, congestion, degradation and regeneration, were determined. The results revealed that the livers of mice in the BSA control and Dox groups exhibited cell necrosis, infiltration as a result of central vein dilation and lymphocytosis (Fig. 5). By contrast, the kidney and spleen of mice among all groups did not exhibit any significant pathological alterations (Fig. 5).

Effect of cecropinXJ on HIS, KSI, thymus index and spleen index. As demonstrated in Table III, the thymus and spleen indexes in mice treated with Dox were not significantly different when compared with the BSA control group. However, the thymus and spleen indexes of mice treated with cecropin XJ were significantly increased when compared with the BSA group. When compared with the normal healthy control group, the thymus index of mice in Dox group was decreased, however, this did not reach statistical significance (Table III). Mice in the cecropinXJ treatment group displayed the highest thymus and spleen indexes among the tumor-bearing mice.

\section{Discussion}

Malignant ascites and peritoneal metastases develop due to metastasis of malignant tumor cells to the peritoneum. It is known that $\sim 50 \%$ patients with advanced or recurrent malignant tumors develop varying degrees of malignant ascites (19). Once this occurs, the survival of patients is usually 5-7 months (20). For gastroenteric tumors, peritoneal or abdominal visceral metastasis is the primary cause of tumor recurrence and is a key prognostic factor. The survival rate for these patients is only 3 months (21). Therefore, it is of value to identify novel drugs to enhance the survival and quality of life of patients.

CecropinXJ may effectively inhibit the proliferation of human gastric cancer BGC823 cells (12). Studies investigating the effect of cecropinXJ on the growth of malignant ascites tumors are 
Table III. Effect cecropinXJ treatment on immune organ indexes.

\begin{tabular}{lcccc}
\hline Parameter & $\begin{array}{c}\text { Healthy } \\
\text { mice group }\end{array}$ & $\begin{array}{c}\text { Negative control } \\
\text { group (BSA) }\end{array}$ & $\begin{array}{c}\text { CecropinXJ } \\
\text { treatment group }\end{array}$ & $\begin{array}{c}\text { Positive control } \\
\text { group (Dox) }\end{array}$ \\
\hline Number & 10 & 10 & 10 & 10 \\
HSI (\%) & $6.36 \pm 1.82$ & $8.66 \pm 0.39$ & $8.08 \pm 1.57$ & $6.70 \pm 0.40$ \\
KSI (\%) & $0.90 \pm 0.40$ & $1.32 \pm 0.43$ & $1.89 \pm 0.20$ & $1.32 \pm 0.09$ \\
Thymus index & $19.72 \pm 3.73$ & $12.28 \pm 2.75$ & $33.06 \pm 1.15^{\mathrm{d}, \mathrm{e}}$ & $17.27 \pm 3.53$ \\
Spleen index & $60.77 \pm 3.94$ & $150.82 \pm 1.29^{\mathrm{b}}$ & $190.35 \pm 1.44^{\mathrm{c}}$ & $130.78 \pm 1.31$ \\
\hline
\end{tabular}

Data are expressed as the mean \pm standard error of three mice in each group. ${ }^{\mathrm{a}} \mathrm{P}<0.05$ and ${ }^{\mathrm{b}} \mathrm{P}<0.01$ vs. healthy group. ${ }^{\mathrm{c}} \mathrm{P}<0.05$ and ${ }^{\mathrm{d}} \mathrm{P}<0.01$ vs. BSA group. ${ }^{e} \mathrm{P}<0.05$ and ${ }^{\mathrm{f}} \mathrm{P}<0.01$ vs. Dox group. $\mathrm{N}$, number; BSA, bovine serum albumin; Dox, doxorubicin, HSI, hepatosomatic index; KSI, kidney somatic index.

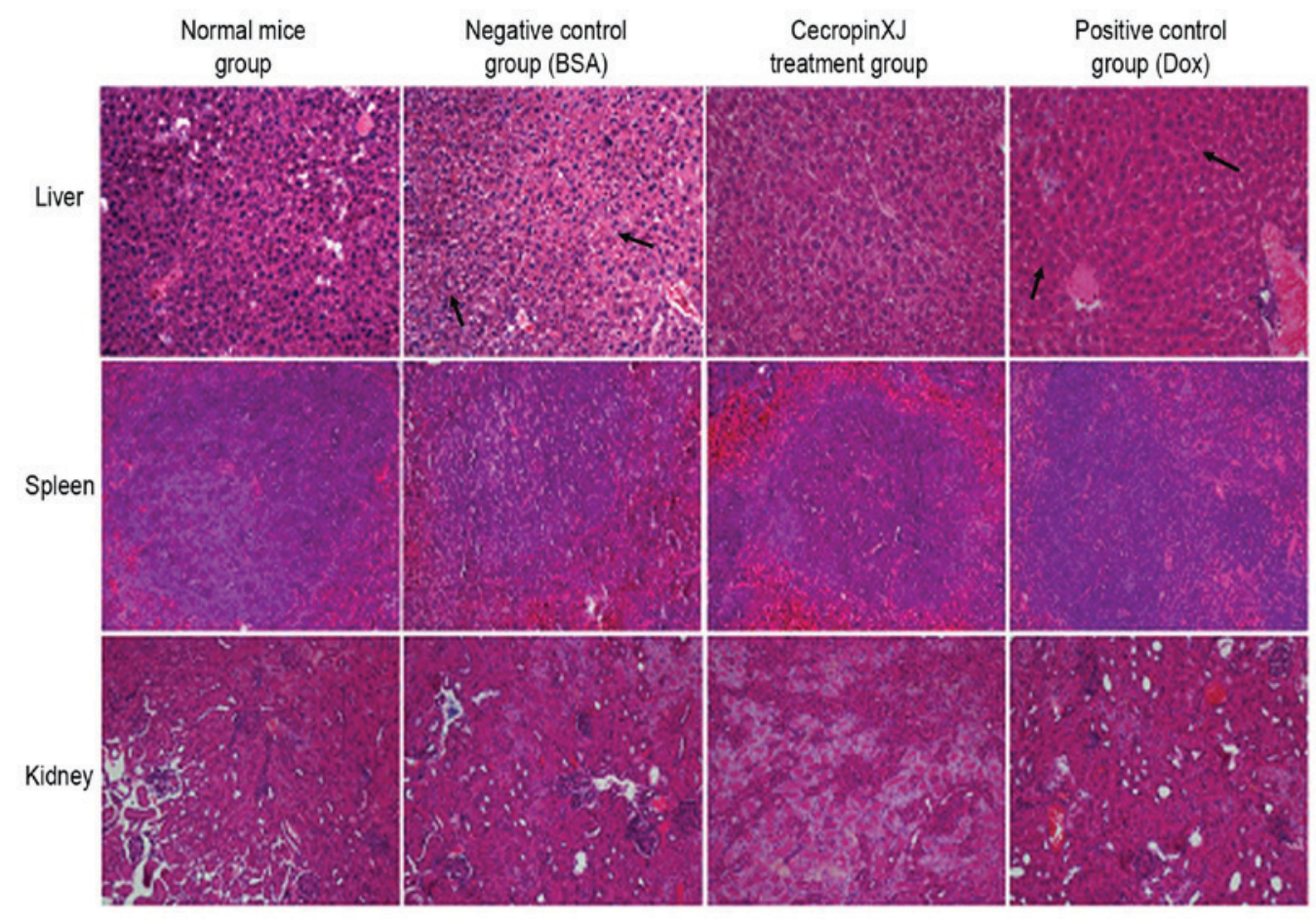

Figure 5. Pathological alterations in the internal organs of mice in each group, as determined by hematoxylin and eosin staining (H\&E, $\mathrm{x} 200$ ). Representative images of staining in the liver, spleen and kidney tissues (magnification, x200). BSA, bovine serum albumin; Dox, doxorubicin.

scarce. In the present study, an ascites model of gastric cancer was established by inoculating BGC 823 cells into the peritoneal cavity of mice. In this model, cecropinXJ was observed to inhibit the growth and progression of ascites tumors in the peritoneal cavity, and induce tumor cell apoptosis in ascites fluid. These results suggested that intraperitoneal injection of cecropinXJ in mice demonstrated an anti-tumor effect, and that the cytotoxic effects may have been due to increased apoptosis.

Traditional chemotherapy and radiotherapy drugs frequently have the toxic effects that may be observed by changes in blood parameters (22) and viscera (23), which may affect the quality of life of patients. Important factors used to determine the efficacy of anti-cancer drugs include patient survival, the degree of tumor growth inhibition and the reduction in tumor cell numbers $(24,25)$. The results of the present study suggest that cecropinXJ may significantly prolong the survival of tumor-bearing mice, and demonstrated limited toxicity to vital organs. Bone marrow suppression and anemia, as indicated by a decrease in hemoglobin and red blood cells, are frequently observed in patients with ascites tumors (26). There is a high incidence of anemia in patients with gastrointestinal cancer (27). White blood cells, including neutrophils, lymphocytes and monocytes, are key cells of the immune system. Under pathological conditions, the numbers of white blood cells are enhanced and an inflammatory reaction is induced. In the present study, intraperitoneal injection of cecropinXJ significantly increased hemoglobin levels and the number of red blood cells, while the number of white blood cells was decreased, when compared with tumor-bearing mice treated with BSA. In addition, the level of red blood cells in the cecropinXJ groups were similar to healthy mice. These results suggested that cecropinXJ may protect hematological 
activity without inducing bone marrow toxicity, which is the most common side effect of chemotherapy drugs. But the above results need to be confirmed and validated furher.

In the present study, the pathological alterations in visceral organs of tumor-bearing mice treated with cecropinXJ were analyzed following hematoxylin and eosin staining. The results revealed that cecropinXJ treatment was associated with low-level toxicity to visceral organs, including the liver, spleen and kidney. In addition, cecropinXJ exhibited selective cytotoxicity to tumor cells. Therefore, cecropinXJ may be useful as an anti-tumor agent for ascites in patients with gastric cancer.

Evasion of the immune system is beneficial to tumor development. The thymus is a key immune organ and the spleen is an important peripheral immune organ. The thymus and spleen indexes may be used to directly reflect the level of immune function in humans. When ascites tumors form in mice, abnormalities in immune organ function is indicated by a decrease in spleen and thymus indexes (28). In the present study, the thymus index in the Dox group was decreased compared with healthy control group, indicating that the immune function of mice was suppressed and may have been the cause of the reduced survival in these mice. Compared with the mice in the Dox and BSA groups, the thymus index and spleen index of the mice in the cecropinXJ treatment group were significantly enhanced. This suggested that cecropin XJ may have reduced injury to viscera in tumor-bearing mice, and was not toxic to the thymus and spleen. This may facilitate maintenance of immune function, inhibit tumor growth, increase immunity and improve quality of life.

In conclusion, the results of the current study demonstrated that cecropinXJ may effectively inhibit ascites formation in mice bearing tumors derived from gastric cancer cells. In addition, cecropinXJ may prolong survival and exhibit anti-tumor effects via induction of apoptosis and enhanced immunity. Notably, cecropinXJ demonstrated no obvious side effects in tumor-bearing mice. Therefore, cecropinXJ may be useful as an anti-cancer agent for the treatment of ascites in gastric cancer patients.

\section{Acknowledgements}

We thank Professor Youyong Lv for providing the gastric cancer BGC823 cells.

\section{Funding}

The present study was supported by the National Natural Science Foundation of China (grant no. 31500752), the Doctoral Start-up Fund of Xinjiang University (grant no. BS150241) and the High-Tech Research and Development Program of Xinjiang (grant no. 201110101).

\section{Availability of data and materials}

The datasets used and analyzed during the current study are available from the corresponding author on reasonable request.

\section{Authors' contributions}

LJX analyzed and interpreted the data of the present study, and was a major contributor in writing the manuscript. YLW performed the histological examination of the mouse, and physiological and biochemical analysis. JM and FCZ made substantial contribution to the study conception and design. FCZ was involved in the drafting of the manuscript and gave the final approval to be published. All authors read and approved the manuscript.

\section{Ethics approval and consent to participate}

The present study is licensed under a Creative Commons Attribution-NonCommercial-NoDerivatives 4.0 International (CC BY-NC-ND 4.0) License.

\section{Consent for publication}

Not applicable.

\section{Competing interests}

Authors declare that they have no competing interests.

\section{References}

1. Parsons SL, Watson SA and Steele RJ: Malignant ascites. Br J Surg 83: 6-14, 1996.

2. Runyon BA: Care of patients with ascites. N Engl J Med 330: 337-342, 1994.

3. Sasako M: Principles of surgical treatment for curable gastric cancer. J Clin Oncol 21 (23 Suppl): 274s-275s, 2003.

4. Becker G, Galandi D and Blum HE: Malignant ascite: Systematic review and guideline for treatment. Eur J Cancer 42: 589-597, 2006.

5. Smith EM and Jayson GC: The current and future management of malignant ascites. Clin Oncol (R Coll Radiol) 15: 59-72, 2003.

6. Cruciani RA, Barker JL, Zasloff M, Chen HC and Colamonici O: Antibiotic magainins exert cytolytic activity against transformed cell lines through channel formation. Proc Natl Acad Sci USA 88: 3792-3796, 1991.

7. Jin XB, Li XB, Zhu JY, Lu XM, Shen J, Chu FJ and Mei HF: The target of Musca domestica cecropin on human hepatocellular carcinoma BEL-7402 cells. Zhongguo Ji Sheng Chong Xue Yu Ji Sheng Chong Bing Za Zhi 29: 271-273, 2011 (In Chinese).

8. Jin XB, Wang YJ, Liang LL, Pu QH, Shen J, Lu XM, Chu FJ and Zhu JY: Cecropin suppresses human hepatocellular carcinoma BEL-7402 cell growth and survival in vivo without side-toxicity. Asian Pac J Cancer Prev 15: 5433-5436, 2014.

9. Liu Z, Zhang F, Cai L, Zhao G and Wang B: Studies on the properties of cecropin-XJ expressed in yeast from Xinjiang silkworm. Wei Sheng Wu Xue Bao 43: 635-641, 2003 (In Chinese).

10. Xia L, Zhang F, Liu Z, Ma J and Yang J: Expression and characterization of cecropinXJ, a bioactive antimicrobial peptide from Bombyx mori (Bombycidae, Lepidoptera) in Escherichia coli. Exp Ther Med 5: 1745-1751, 2013.

11. Xia L, Liu Z, Ma J, Sun S, Yang J and Zhang F: Expression, purification and characterization of cecropin antibacterial peptide from Bombyx mori in Saccharomyces cerevisiae. Protein Expr Purif 90: 47-54, 2013.

12. Wu YL, Xia LJ, Li JY and Zhang FC: CecropinXJ inhibits the proliferation of human gastric cancer BGC823 cells and induces cell death in vitro and in vivo. Int J Oncol 46: 2181-2193, 2015.

13. Xia L, Wu Y, Kang S, Ma J, Yang J and Zhang F: CecropinXJ, a silkworm antimicrobial peptide, induces cytoskeleton disruption in esophageal carcinoma cells. Acta Biochim Biophys Sin (Shanghai) 46: 867-876, 2014.

14. Wu Y, Xia L and Zhang F: Inhibition of CecropinXJ on proliferation of human gastric cancer AGS cells. Chin J Cell Biol 36: 1355-1361, 2014 (In Chinese).

15. Fung KY, Ooi CC, Zucker MH, Lockett T, Williams DB, Cosgrove LJ and Topping DL: Colorectal carcinogenesis: A cellular response to sustained risk environment. Int J Mol Sci 14: 13525-13541, 2013.

16. Lettre H: Tests of compounds against the Ehrlich mouse ascites tumor. Cancer Res 2 (Suppl): S125-S128, 1955. 
17. Sugiura K: Effect of various compounds on the Ehrlich ascites carcinoma. Cancer Res 13: 431-441, 1953.

18. Dagistan Y, Dagistan E and Citisli V: Evaluation of simple blood counts as inflammation markers for brain tumor patients. Neurol Neurochir Pol 50: 231-235, 2016.

19. Sedláková O, Sedlák J, Hunáková L, Jakubíková J, Duraj J, Sulíková M, Chovancová J and Chorváth B: Angiogenesis inhibitor TNP-470: Cytotoxic effects on human neoplastic cell lines. Neoplasma 46: 283-289, 1999.

20. Yoshizawa J, Mizuno R, Yoshida T, Hara A, Ashizuka S, Kanai M, Kuwashima N, Kurobe M and Yamazaki Y: Inhibitory effect of TNP-470 on hepatic metastasis of mouse neuroblastoma. J Surg Res 93: 82-87, 2000.

21. Oey RC, van Buuren HR and de Man RA: The diagnostic work-up in patients with ascites: Current guidelines and future prospects. Neth J Med 74: 330-335, 2016.

22. Sostelly A, Henin E, Chauvenet L, Hardy-Bessard AC, Jestin-Le Tallec V, Kirsher S, Leyronnas C, Ligeza-Poisson C, Ramdane S, Salavt J, et al: Can we predict chemo-induced hematotoxicity in elderly patients treated with pegylated liposomal doxorubicin? Results of a population-based model derived from the DOGMES phase II trial of the GINECO. J Geriatr Oncol 4: 48-57, 2013.

23. Zolfagharzadeh F and Roshan VD: Pretreatment hepatoprotective effect of regular aerobic training against hepatic toxicity induced by Doxorubicin in rats. Asian Pac J Cancer Prev 14 2931-2936, 2013
24. Hogland HC: Hematologic complications of cancer chemotherapy. Semin Oncol 9: 95-102, 1982.

25. Arora S, Jain J, Rajwade JM and Paknikar KM: Cellular responses induced by silver nanoparticles: In vitro studies. Toxicol Lett 179: 93-100, 2008.

26. Maseki M, Nishigaki I, Hagihara M, Tomoda Y and Yagi K: Lipid peroxide levels and lipids content of serum lipoprotein fractions of pregnant subjects with or without pre-eclampsia. Clin Chim Acta 115: 155-161, 1981.

27. Verhaeghe L, Bruyneel L, Stragier E, Ferrante M, Dierickx D and Prenen H: The effectiveness of intravenous iron for iron deficiency anemia in gastrointestinal cancer patients: A retrospective study. Ann Gastroenterol 30: 654-663, 2017.

28. Dong JF, Zheng XQ and Rui HB: Effect of taurine on immune function in mice with T-cell lymphoma during chemotherapy. Asian Pac J Trop Med 10: 1090-1094, 2017.

(i) (9) This work is licensed under a Creative Commons Attribution-NonCommercial-NoDerivatives 4.0 International (CC BY-NC-ND 4.0) License. 